\title{
PENGARUH METODE ANALISIS TABLET PARASETAMOL TERHADAP NILAI AKURASI
}

\author{
Vevi Maritha, Kuncara Nata Waskita \\ Program Studi S1 Farmasi, Stikes Bhakti Husada Mulia Madiun \\ E-mail:vv.maritha@gmail.com
}

\begin{abstract}
ABSTRAK
Parasetamol adalah senyawa yang memiliki gugus kromofor sehingga dapat dianalisis menggunakan spektrofotometri. Metode nitrimetri memiliki kelebihan peralatan yang digunakan sederhana, sedangkan spektrofotometri memiliki kelebihan jumlah sampel yang dianalisis sedikit. Nitrimetri dan spektrofotometri adalah metode analisis yang memiliki nilai akurasi yang tinggi untuk analisis parasetamol dalam sediaan tablet. Analisis Parasetamol menggunakan metode nitrimetri dengan cara diambil 20 tablet parasetamol, dihitung rata-ratanya . timbang sejumlah rata-rata tablet masukkan dalam $20 \mathrm{ml}$ larutan $\mathrm{HCl}:$ air $(1: 2)$, kemudian stirrer selama 20 menit. Tambahkan 5 gram KBr, 5 tetes tropeolin OO dan 3 tetes metilen blue. Titrasi dengan larutan NaNO2 0,1 M. titrasi dihentikan apabila terjadi perubahan warna dari ungu ke biru terang. Kemudian dihitung kadar parasetamol, replikasi 2 x. Sedangkan analisis parasetamol menggunakan spektrofotometri adalah dengan pembuatan kurva baku baru analisis sampel. Hasil dari penelitian ini bahwa nilai akurasi analisis parasetamol menggunakan metode nitrimetri adalah $94 \%$ sampai dengan $103,48 \%$. Nilai akurasi analisis parasetamol menggunakan spektrofometri adalah 98,8 \% sampai dengan 101,79\%. Hal ini menunjukkan bahwa nilai akurasi pada analisis parasetamol masuk dalam range yang dipersyaratkan AOAC. Dari hasil analisis ini metode spektrofometri lebih baik dari pada metode nitrimetri sebab metode spektrofometri memiliki keunggulan dalam hal selektivitas dan sensitivitas. Selektivitas berarti bahwa metode ini dapat menganalisis dengan benar parasetamol, sedangkan sensitivitas adalah dengan kadar yang kecil metode ini dapat mendeteksi. Selektivitas dan sensitivitas yang tinggi pada metode spektrofotometri menghasilkan nilai akurasi yang tinggi dan memenuhi nilai akurasi yang dipersyaratkan AOAC. Hasil analisis data menggunakan uji independen $t$-test adalah nilai signifikansi 0.970 yang artinya terdapat perbedaan signifikan antara metode nitrimetri dan spektrofotometri terhadapa nilai akurasi.
\end{abstract}

Kata kunci : Metode Analisis, Nitrimetri, Parasetamol, Spektrofotometri

\begin{abstract}
:
Paracetamol is a compound that has a chromophore group so that it can be analyzed using spectrophotometry. The nitrimetry method has the advantage of simple equipment, while spectrophotometry has the advantage of a small number of samples being analyzed. Nitrimetry and spectrophotometry are analytical methods that have high accuracy values for the analysis of paracetamol in tablet preparations. Analysis of paracetamol using the nitrimetry method by taking 20 paracetamol tablets, the average was calculated. weigh an average number of tablets put in $20 \mathrm{ml}$ of a solution of $\mathrm{HCl}$ : water (1: 2), then stirrer for 20 minutes. Add 5 grams of $\mathrm{KBr}, 5$ drops of tropeolin $\mathrm{OO}$ and 3 drops of methylene blue. Titration with $0.1 \mathrm{M}$ NaNO2 solution is stopped when the color changes from purple to bright blue. Then calculated levels of paracetamol, replication $2 x$. Whereas paracetamol analysis using spectrophotometry is by making a new standard curve analysis of samples. The results of this study indicate that the accuracy of paracetamol analysis using nitrimetry methods is $94 \%$ to $103.48 \%$. The accuracy value of paracetamol analysis using spectropometry is $98.8 \%$ to $101.79 \%$. This shows that the accuracy value in paracetamol analysis falls within the range required by AOAC. From the results of this analysis the spectropometric method is better than the nitrimetric method. This is because the spectropometric method has advantages in terms of selectivity and sensitivity. Selectivity means that this method can correctly analyze paracetamol, while sensitivity is to a small degree this method can detect. High selectivity and sensitivity in spectrophotometry methods produce high accuracy values and meet the accuracy values required by AOAC. The results of data analysis using independent $t$-test is a significance value of 0.970, which means that there are significant differences between the nitrimetric and spectrophotometric methods of accuracy.
\end{abstract}

Keyword : Method analysis, Nitrimetri, Paracetamol, Spectrofotometri 


\section{PENDAHULUAN}

Parasetamol adalah obat golongan analgesic antipiretik yang banyak digunakan. Parasetamol bekerja dengan cara menghambat sintesis prostaglandin yang merupakan mediator nyeri, sehingga efektif sebagai analgesik. Efek antipiretik parasetamol ditimbulkan karena adanya gugus amino benzene yang menurunkan demam saat panas. Parasetamol banyak digunakan sebagai analgesic antiporetik baik pada anak-anak maupun dewasa. Minimnya efek samping adalah salah satu alasan penggunaan parasetamol secara luas. Sediaan parasetamol yang banyak digunakan adalah tablet. Hal ini dikarenakan sediaan tablet parasetamol lebih praktis, mudah digunakan serta mudah penyimpanan (Gianita $\mathrm{P}$ dan Taufik E, 2016).

Untuk menjamin kualitas sediaan tablet parasetamol adalah dengan memastikan kadar zat aktif yang memenuhi persyaratan. Untuk mengetahui kadar zat aktif diperlukan metode analisis yang baik. Metode analisis yang dapat digunakan untuk analisis kadar parasetamol dalam sediaan tablet adalah nitrimetri dan spektofotometri. Nitrimetri merupakan metode analisis pada senyawa yang memiliki gugus amin aromatic primer atau senyawa lain yang bisa dihidrolisis menjadi amin aromatic sekunder. Parasetamol adalah senyawa yang memiliki gugus amin sehingga dapat dianalisis menggunakan parasetamol. Spektrofotometri adalah metode senyawa yang memiliki gugus kromofor. Parasetamol adalah senyawa yang memiliki gugus kromofor sehingga dapat dianalisis menggunakan spektrofotometri. Metode nitrimetri memiliki kelebihan peralatan yang digunakan sederhana, sedangkan spektrofotometri memiliki kelebihan jumlah sampel yang dianalisis sedikit. Nitrimetri dan spektrofotometri adalah metode analisis yang memiliki nilai akurasi yang tinggi untuk analisis parasetamol dalam sediaan tablet (Fithria, 2012; Lily 2016).

Akurasi dari suatu metode analisis ditentukan dari nilai recoveri (perolehan kembali) seperti yang di persyaratkan oleh AOAC. Nilai recovery sediaan yang mengandung zat aktif $500 \mathrm{mg}$ adalah $98 \%$ - 102\%. Nilai recovery yang sesuai dengan standar AOAC menunjukkan bahwa metode analisis yang digunakan memiliki akurasi yang baik. Nitrimetri dan Spektrofometri yang digunakan untuk analisis tablet parasetamol yang samasama memiliki nilai akurasi yang baik. Untuk itu perlu dilakukan penelitian untuk melihat apakah ada perbedaan yang 
bermakna antara metode analisis parasetamol pada sediaan tablet menggunakan nitrimetri dan spektrofotometri terhadap nilai akurasi (AOAC, 1998 ).

\section{METODE}

Jenis penelitian ini adalah ekperimental. Lokasi penelitian di laboratorium Kimia STIKES Bhakti Husada Mulia Madiun. Waktu penelitian adalah bulan Mei sampai dengan Juli 2017. Bahan yang digunakan dalam penelitian ini adalah parasetamol standar, sampel tablet parasetamol, asam sulfanilat, $\mathrm{NaNO}$, Amoniak 25\%, $\mathrm{HCl}$ pekat, $\mathrm{KBr}$, Metilen Blue $0,1 \%$, Tropeolin OO $0,1 \%$. Beker gelas, pipet tetes, buret, Erlenmeyer, neraca analitik, spektrofotometer. Analisis data menggunakan independen t-testt.

\section{Analisis Parasetamol Secara Nitrimetri}

Diambil 20 tablet parasetamol, dihitung rata-ratanya . timbang sejumlah rata-rata tablet masukkan dalam $20 \mathrm{ml}$ larutan $\mathrm{HCl}$ : air (1:2), kemudian stirrer selama 20 menit. Tambahkan 5 gram $\mathrm{KBr}, 5$ tetes tropeolin OO dan 3 tetes metilen blue. Titrasi dengan larutan NaNO2 0,1 $\mathrm{M}$. titrasi dihentikan apabila terjadi perubahan warna dari ungu ke biru terang. Kemudian dihitung kadar parasetamol, replikasi $2 \mathrm{x}$.

\section{Analisis Parasetamol Secara Spektrofotometri}

1. Penentuan panjang gelombang maksimal

Buat kadar parasetamol 100 ppm dari baku induk dengan cara pengenceran. Masukkan dalam kuvet. Masukkan dalam spektrofotometer dengan blangko aquades. Cari panjang gelombang maksimal

2. Pembuatan kurva baku

Dibuar seri kadar 50ppm, 60 ppm, 70 ppm, 80 ppm, 90 ppm, 100 ppm, 110 ppm, 120 ppm, 130 ppm dan 140 ppm. Masukkan dalam spektrofotometer, lakukan pembacaan absorbansi pada panjang gelombang maksimal yang sudah di cari sebelumnya. Buat kurva dan persamaan regresinya

3. Penentapan kadar parasetamol Timbang 20 tablet sampel, hitung nilai rata-ratanya. Gerus dan ambil sejumlah bobot rata-ratanya. Masukkan dalam labu ukur $100 \mathrm{ml}$ tambahkan aquades, Stirer dan Saring. Lakukan pembacaan nilai absorbansinya menggunkan spektrofotometer. Hitung kadar sampel menggunakan persamaan regresi

\section{HASIL}

Pada penelitian ini hasil analisis 
kadar parasetamol menggunakan metode nitrimetri adalah 95 ppm, 104 ppm dan 102 ppm. Panjang gelombang maksimal analisis parasetamol menggunakan spektrofotometri adalah $293 \mathrm{~nm}$. Kurva baku parasetamol yang diperoleh tersaji pada tabel 1 dan gambar 1 dengan persamaan regresi $\mathrm{y}=0.0031 \mathrm{x}+0.0918$ dan nilai $\mathrm{r}=0.97$. hasil analisis kadar parasetamol secara spektrofotometri adalah 100 ppm, 98 ppm dan 102 ppm. Hasil recovery analisis parasetamol menggunakan nitrimetri dan spektrofotometri terdapat pada tabel 2 .

Tabel 1. Kurva Baku Parasetamol

\begin{tabular}{ccc}
\hline No & Kadar $(\mathbf{p p m})$ & Absorbansi \\
\hline $\mathbf{1}$ & 80 & 0.322 \\
$\mathbf{2}$ & 100 & 0.424 \\
$\mathbf{3}$ & 120 & 0.471 \\
$\mathbf{4}$ & 130 & 0.505 \\
$\mathbf{5}$ & 140 & 0.507 \\
\hline
\end{tabular}

\section{Kurva Baku Parasetamol}

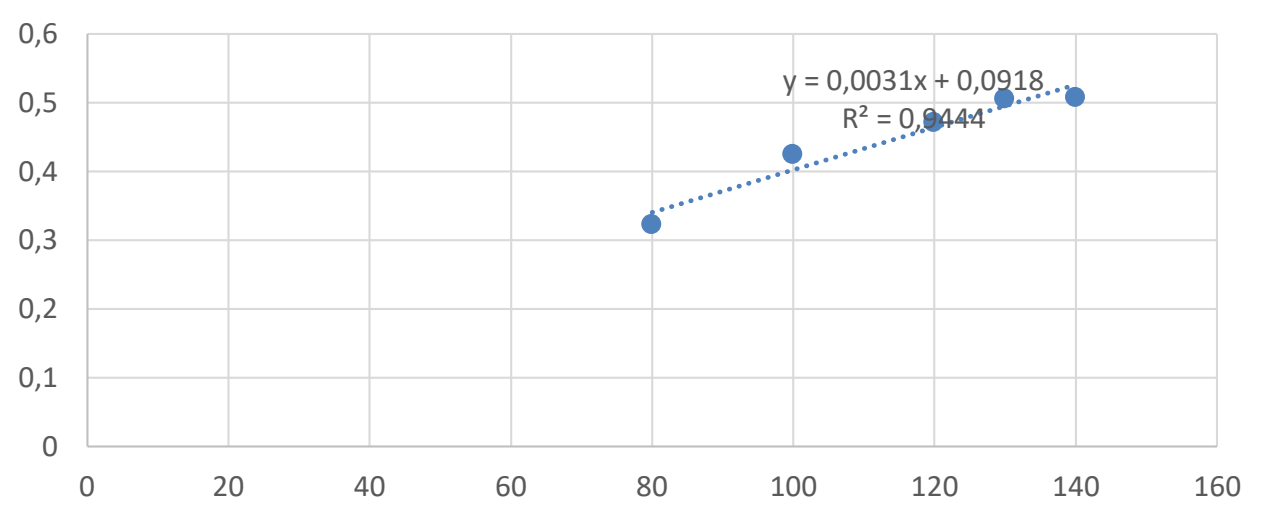

Gambar 1. Kurva Baku Parasetamol

Tabel 2. Hasil \% Recovery Analisis Tablet Parasetamol

\begin{tabular}{lcccc}
\hline Metode & Replikasi & $\begin{array}{c}\text { Kadar Teoritis } \\
(\mathbf{p p m})\end{array}$ & $\begin{array}{c}\text { Kadar yang diperoleh } \\
\text { kembali }(\mathbf{p p m})\end{array}$ & \% Recovery \\
\hline Nitrimetri & 1 & 100,5 & 95 & 94 \\
& 2 & 100,5 & 104 & 103,48 \\
\multirow{3}{*}{ Spektrofometri } & 3 & 100,5 & 102 & 101,49 \\
& 1 & 100,2 & 100 & 99,8 \\
& 2 & 100,2 & 99 & 98,8 \\
& 3 & 100,2 & 102 & 101,79 \\
\hline
\end{tabular}


Hasil analisis data menggunakan uji independen $t$-test adalah nilai signifikansi 0.970 yang artinya terdapat perbedaan signifikan antara metode nitrimetri dan spektrofotometri terhadap nilai akurasi.

\section{DISKUSI}

Penelitian ini bertujuan untuk mengetahui perbedaan metode analisis parasetamol pada sediaan tablet terhadap nilai akurasi. Akurasi adalah ketelitian metode analisis atau ketepatan antara nilai tertukur dengan nilai yang diterima baik nilai konfensi nilai sebenarnya atau nilai rujukan akurasi diukur sebagai banyaknya analit yang diperoleh kembali pada suatu pengukuran dengan melakukan spiking pada suatu sampel. Nilai akurasi dilihat dari perolehan kembali (\% recovery). Untuk sediaan tablet parasetamol $500 \mathrm{mg}$ maka \% recovery adalah $98 \%$ sampai dengan $102 \%$.

Hasil dari penelitian ini bahwa nilai akurasi anasisi parasetamol menggunakan metode nitrimetri adalah $94 \%$ sampai dengan $103,48 \%$. Hal ini menunjukkan bahwa nilai akurasi pada analisis parasetamol tidak masuk dalam range yang dipersyaratkan AOAC. Hal ini bisa terjadi dikarenakan metode ini memang kurang spesifik untuk analisis suatui zat serta penggunaan indicator luar yang sukar menentukan titik akhir titrasinya. Nilai akurasi analisis parasetamol menggunakan spektrofometri adalah 98,8 \% sampai dengan 101,79\%. Hal ini menunjukkan bahwa nilai akurasi pada analisis parasetamol masuk dalam range yang dipersyaratkan AOAC. Dari hasil analisis ini metode spektrofometri lebih baik dari pada metode nitrimetri. Hal ini dikarenakan metode spektrofometri memiliki keunggulan dalam hal selektivitas dan sensitivitas. Selektivitas berarti bahwa metode ini dapat menganalisis dengan benar parasetamol, sedangkan sensitivitas adalah dengan kadar yang kecil metode ini dapat mendeteksi. Selektivitas dan sensitivitas yang tinggi pada metode spektrofotometri menghasilkan nilai akurasi yang tinggi dan memenuhi nilai akurasi yang dipersyaratkan AOAC. (Putra dan Sugiarso, 2016 ; Lema et al, 2014)

Pada uji statistic menggunakan $t$ test diperoleh hasil signifikansi 0.970 yang artinya terdapat perbedaan signifikan antara metode nitrimetri dan spektrofotometri terhadapa nilai akurasi. Berdasarkan uji statistic nilai akurasi analisis parasetamol menggunakan 
metode nitrimetri dan spektrofotometri menunjukkan hasil yang signifikan berbeda.

\section{KESIMPULAN}

Kesimpulan dari penelitian ini adalah metode analisis tablet parasetamol berpengaruh secara signifikan terhadap nilai akurasi.

\section{DAFTAR PUSTAKA}

AOAC. AOAC Peer-Verified Methods Program,Manual on Policies and Procedures. Arlington,Amerika Serikat:AOAC. 1998.

Fithriani, A; Rusdi dan Ehrlich V. 2012. Penggunaan Metode Ratio Absorban Dalam Penetapan Kadar Parasetamol Dan Slisilamid Berbentuk Sediaan Campuran. Jurnal Sains dan Teknologi Farmasi. Vol 17 No 2. Pp 172-184
Gianita, P dan Taufik Eko. Pengaruh Pemberian Analgesik Kombinasi Parasetamol dan Tramadol Terhadap kadar Kreatinin Serum Tikus Wistar. Jurnal Kedokteran Diponegoro. 2016. Vol 5 No 4 : 917-925

Lema, A ; Sulistyarti, H dan Atikah. Pengembangan Metode

Spektrofotometri Untuk Penentuan Iodida Menggunakan Hidrogen Peroksida $\left(\mathrm{H}_{2} \mathrm{O}_{2}\right)$ Sebagai Oksidator. Natural B. Vol 2 No 4. Pp 308-3015 Lily C. 2016. Analisis Kuantitatif Bahan Baku Parasetamol Dengan Metode Nitrimetri. Universitas Padjajaran. Bandung. Pp 1-8

Putra F dan Sugiarso R. 2016. Perbandingan Metode Analisis Permanganometri dan Serimetri Dalam Penentuan Kadar Besi (II). Jurnal Sains dan Seni ITS. Vol 5 No 1. Pp 1-4 
